Mr Sead Cvrk, potpukovnik, dipl. inž. VP 8420 , Bar

\section{ODREĐIVANJE PROPELERSKE \\ ODREĐIVANJE PROPELERSKE
KARAKTERISTIKE MOTORA POMOĆU MJERNIH TRAKA I PERSONALNOG RAČUNARA U USLOVIMA EKSPLOATACIJE NA BRODU}

UDC: $621.436: 623.82]: 004.382 .7$

Rezime:

U ovom radu opisan je postupak mjerenja deformacija propelerskog vratila pomoću mjernih traka i personalnih računara, beskontaktnom metodom. Na osnovu poznatog poprečnog presjeka, kao i vrste materijala propelerskog vratila, odredivan je obrtni moment. Poznavajući frekvenciju vratila, odnosno ugaonu brzinu i obrtni moment, moguće je odrediti efektivnu snagu koja se prenosi od motora na propeler. Oprema, odnosno hardver $i$ softver koji je korišten u radu proizvedeni su u njemačkoj firmi „Hottinger baldwin messtehnik“" (HBM). Eksperiment je izvršen na brodu Mornarice Vojske Srbije i Crne Gore u uslovima ustaljenog režima plovidbe.

Ključne reči: brod, dizel motor, efektivna snaga, mjerne trake.

\title{
DETERMINANTING THE PROPELLER CHARACTERISTIC OF THE ENGINE BY MEANS OF STRAIN GAUGES AND PERSONAL COMPUTERS IN THE CONDITIONS OF EXPLOTATION ON A SHIP
}

Summary:

In this paper, there has been described the way of measuring propeller shaft deformation using the strain gauges and PCs by means of the non-contact method. On the basis of the known cross-section as well as the propeller shaft material type the torque has been calculated. Knowing the shaft frequency, that is the radial velocity and the torque, it is possible to determine the effective power that has been transmitted from the engine to the propeller. The equipment, that is the hardware and the software that have been used, was produced by HOTTINGER BALDWIN MESSTEHNIK (HBM), Darmstadt, the Federal Republic of Germany. The experiment has been carried out on a ship belonging to the Navy of Serbia and Montenegro in the conditions of the usual sailing regime.

Key words: ship, diesel engine, effective power, strain gauges.

\section{Uvod}

U toku eksploatacije motora njegova snaga se stalno mijenja, zavisno od priključenog potrošača. U uslovima pogona broda, snaga koju motor predaje propeleru sa nepromjenljivim korakom krila zavisi od broja obrtaja i koraka krila propelera. Otpor koji pruža propeler ne- promjenljivog koraka krila, a koji motor savlađuje, proporcionalan je kvadratu broja obrtaja propelera:

$M=k \cdot n^{2}$

Efektivna snaga koju motor predaje propeleru može da se izrazi preko obrtnog momenta koji se sa koljenastog vratila 
prenosi preko spojnice na propeler, pri čemu se on obrće ugaonom brzinom $\omega$ :

$P_{e}=M \cdot \omega$

U slučaju kada motor pokreće propeler određenog koraka krila, snaga motora koju propeler apsorbuje pri različitim brojevima obrtaja biće [1]:

$$
P_{e}=M \cdot \omega=k \cdot n^{2} \cdot \frac{\pi \cdot n}{30}=k_{1} \cdot n^{3}
$$

gdje je:

$P_{e}$ - snaga koju motor predaje propeleru [W],

$M$ - obrtni moment propelera [Nm],

$n$-broj obrtaja propelera $\left[\mathrm{min}^{-1}\right]$,

$k_{1}$ - konstanta koja zavisi od osobina propelera.

Iz jednačine (3) vidi se da se snaga motora mijenja po kubnoj paraboli $\mathrm{u}$ funkciji promjene broja obrtaja propelera. Ova kriva naziva se propelerska karakteristika motora.

U uslovima eksploatacije motora na brodu veoma je bitno odrediti snagu koju apsorbuje propeler u području od minimalnog do maksimalnog broja obrtaja.

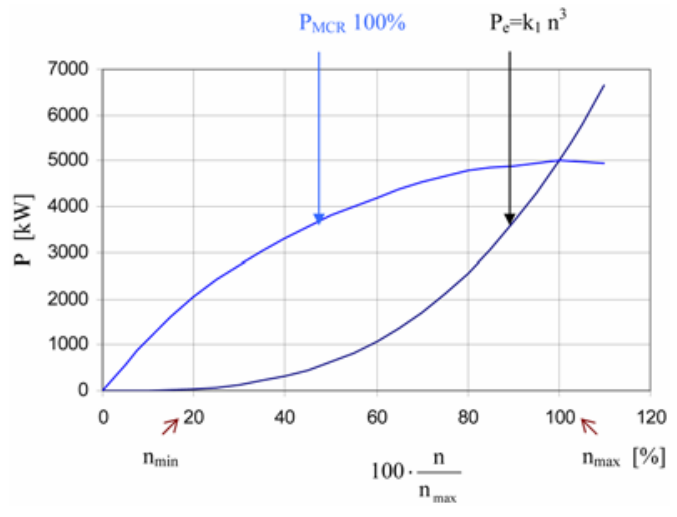

Sl. 1 - Propelerska i spoljna karakteristika motora
$\mathrm{Na}$ osnovu snimljene propelerske karakteristike može se zaključiti na kom režimu motor radi u području mogućih brojeva obrtaja, odnosno da li motor radi po proračunskoj karakteristici obrtnog momenta, karakteristici obrtnog momenta pri plovljenju s ,teškim propelerom“ ili karakteristici obrtnog momenta pri plovljenju s ,lakim propelerom“.

Često se događa da motori ne mogu da razviju potreban broj obrtaja, a brodovi odgovarajuću brzinu. Razlozi za to mogu biti sadržani u promjenjenim spoljašnjim uslovima plovidbe (plovidba u plitkim vodama, kanalima, povećanje gaza broda, plovidba po nevremenu, promjena parametara okoline i drugo) i u promjeni tehničkog stanja i regulacije pojedinih elemenata pogonskog kompleksa: brodskog trupa, propelera, prenosa snage i motora. Očigledno da je zbog mnoštva različitih eksploatacionih faktora, koji utiču na maksimalni broj obrtaja motora, pa time i brzinu plovidbe broda, teško objasniti razloge ove pojave. Zbog toga članovi posade broda koji opslužuju pogonski kompleks, treba dobro da poznaju hidrodinamiku broda, teoriju motora SUS, karakteristike pojedinih elemenata kompleksa, kao i faktore koji na njih utiču. Kada se zna uzrok nekog nedostatka mogu se preduzeti i odgovarajuće pravovremene mjere za njihovo otklanjanje. U brodskim uslovima obično ne postoje instrumenti za mjerenje obrtnog momenta motora (a samim tim i snage) i sile potiska propelera. Zbog toga je potrebno da se, u takvim slučajevima, vrši neposredna kontrola karakteristika trupa, propelera i motora.

Članovima posade broda, koji opslužuju pogonski kompleks, pri rješavanju ovog zadatka, znatnu pomoć pruža 
korišćenje odgovarajućih metoda kontrole rada i tehničkog stanja pojedinih elemenata pogonskog kompleksa broda, a naročito kontrola rada glavnih pogonskih motora.

Jedna od efikasnih metoda pomoću koje se može vršiti mjerenje parametara glavnih motora na brodu, kao i analiza uticaja pojedinih eksploatacionih faktora na rad motora, jeste pomoću mjernih traka (kao i drugih davača izrađenih na principu djelovanja mjernih traka) i personalnih računara. Ovom metodom moguće je uspostaviti funkcionalnu zavisnost između indikatorskih i efektivnih parametara rada motora sa eksploatacionim parametrima, ako se za osnovu uzme bilo koji parametar.

\section{Primjena mjernih traka}

Upotreba mjernih traka danas je veoma raširena, a efikasno se mogu koristiti za analizu napona u konstrukcijama kao što su: jednoosno naponsko stanje, ravansko naponsko stanje, zaostali naponi u konstrukcijama, termički naponi, gradijentni naponi, itd.

Mjerne trake mogu se upotrebljavati za statička, kvazistatička i dinamička mjerenja na konstrukcijama i dijelovima mašina, i to za mjerenje: dilatacija i napona, sile i mase, pritiska, obrtnog momenta, pomjeranja, vibracija, itd.

Kada su u pitanju mjerenja dilatacija i napona, mjerne trake se upotrebljavaju u području elastičnih deformacija prema Hukovom (Hooke) zakonu.

Mjerna traka predstavlja provodnik definisane otpornosti koji je pričvršćen za površinu mjerenog objekta. Svaka deformacija mjerenog objekta, usled njego-

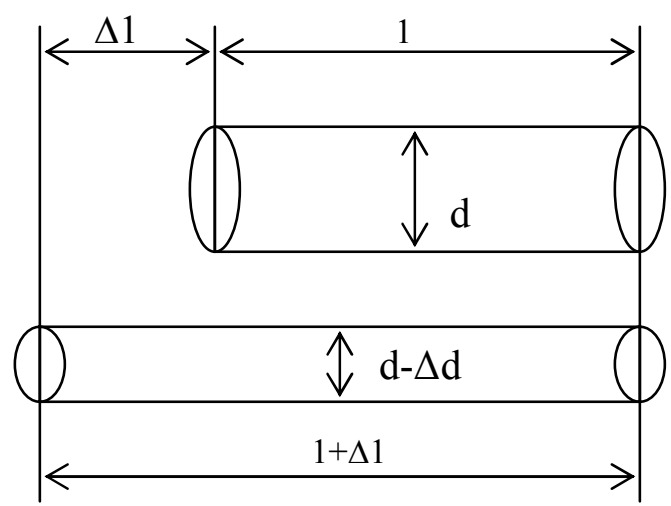

Sl. 2 -Deformacija objekta usled opterećenja

vog opterećenja, izaziva odgovarajuću deformaciju mjerne trake, što sve zajedno omogućava mjerenje promjenjenog otpora.

U neopterećenom stanju otpor mjerne trake je $R_{0}$, a u opterećenom stanju, odnosno posle deformacije, biće $R_{0}+\Delta R$ [2]:

$R_{0}=\frac{\rho \cdot l_{o}}{\mathrm{~A}}=\frac{4 \cdot \rho \cdot l_{o}}{\pi \cdot d^{2}}$

gdje je:

$\rho$ - specifični otpor materijala, $\left[\Omega \mathrm{mm}^{2} / \mathrm{m}\right]$, $l_{o}$ - dužina mjerne trake u neopterećenom stanju, [m],

$\mathrm{A}$ - površina poprečnog presjeka, $\left[\mathrm{m}^{2}\right]$.

Ukupna promjena otpora usled deformacije i promjene mikrostrukture materijala od kojeg je izrađena mjerna traka je:

$\frac{d R}{R_{0}}=\varepsilon \cdot(1+v)+\frac{d \rho}{\rho}$

gdje je:

$\varepsilon=\frac{d l}{l_{o}}-$ relativno izduženje, 
$d l$ - promjena dužine trake

$v$ - Poasonov (Poisson) koeficijent.

Zavisnost između mehaničke deformacije i promjene otpora na mjernoj traci, za različite provodničke materijale, određena je njenom osjetljivošću $k$ [2]:

$k=\frac{\frac{\Delta R}{R_{o}}}{\frac{\Delta l}{l_{o}}}=\frac{\frac{\Delta R}{R_{o}}}{\varepsilon}$

Za različite legure koje se koriste za izradu vlakana u mjernoj traci osjetljivost $k$ je različita. Mjerna traka bi trebalo da mijenja otpor samo usled naprezanja $u$ aktivnom pravcu (pravac u kome se vrši mjerenje) i tada je osjetljivost ( $k$-faktor) definisana kao:

$k_{l}=\frac{\frac{\Delta R}{R_{o}}}{\varepsilon_{l}}$

Ako je mjerna traka opterećena u poprečnom pravcu, tada je odgovarajući $k$-faktor definisan kao:

$k_{t}=\frac{\frac{\Delta R}{R_{o}}}{\varepsilon_{t}}$

Odnos ova dva faktora definiše se kao poprečna osjetljivost:

$q=\frac{k_{t}}{k_{l}}$

Ovaj efekat se redukuje primjenom folijskih mjernih traka sa transverzalnim podebljanjima mreže. Zavisno od tipa mjerne trake i dužine mreže, poprečna osjetljivost $q<0,01-0,02$. Mjerne trake se, u opštem slučaju, upotrebljavaju za mjerenje deformacija do $3000 \mathrm{qm} / \mathrm{m}$. Maksimalno izduženje mjerne trake zavisi od njene konstrukcije i materijala i iznosi od $\pm 2 \mathrm{~cm} / \mathrm{m}$ do $15 \mathrm{~cm} / \mathrm{m}$. U prisustvu velikih deformacija mjerne trake pokazuju nelinearne karakteristike koje se ne mogu smatrati zanemarljivim.

\section{Postavljanje mjernih traka na objekat ispitivanja}

Postavljanje mjerne trake na objekat ispitivanja izvodi se lijepljenjem, uz upotrebu različitih vezivnih materijala i zahtjeva maksimalnu pažnju.

Kao vezivni materijal za lijepljenje mjernih traka upotrebljavaju se: hladno vezujuća lijepila, lijepila koja se vezuju na toplo, keramički kit, tačkasti zavari.

Postavljanje mjernih traka uključuje: čišćenje (mehaničko i hemijsko) površine mjerenog objekta na koju se postavlja tra$\mathrm{ka}$, vezivanje mjerne trake na očišćenu

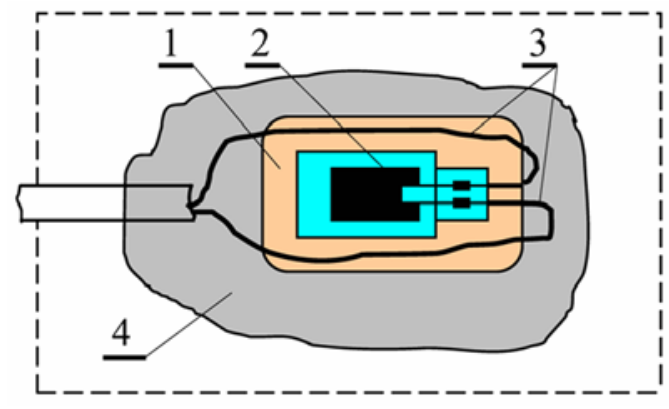

Sl. 3 - Postavljena mjerna traka na objekat ispitivanja:

1 - pripremljena površina na objektu za mjerenje; 2 - postavljena mjerna traka na objekat za mjerenje; 3 - električni provodnici za napajanje mjerne trake 4-specijalna guma za zaštitu mjerne trake 
površinu mjerenog objekta, lemljenje izvoda na terminale za lemljenje, zaštitu mjerne trake (mehanička i hemijska).

Električno povezivanje mjernih traka izvodi se u obliku Vitstonovog (Wheatston) mosta, koji se može upotrijebiti za mjerenje otpora, i to: apsolutnog iznosa otpora, poređenjem sa poznatim otporom i relativne promjene električnog otpora.

$\mathrm{Na}$ ovaj način, povezivanje mjernih traka omogućava mjerenje promjene otpora u granicama od $10^{-4}$ do $10^{-7} \Omega / \Omega$ sa veoma visokom tačnošću. Mjerne trake predstavljaju određene otpornike koji se povezuju od $R_{l}$ do $R_{4}$, kao što je prikazano na slici 4.

U tačkama 2 i 3 spajaju se grane od izvora za napajanje $V_{s}$ bilo jednosmjernim ili naizmjeničnim naponom. U tačkama 1 i 4 dobija se izlazni napon $V_{0}$ koji predstavlja mjereni signal.

Princip rada Vitstonovog mosta može se objasniti uz pomoć slike 5 .

Pretpostavlja se da je otpor izvora napona $R_{G}$ zanemarljiv i da je unutrašnji otpor instrumenta za mjerenje izlaznog napona veoma veliki.

Naponi $V_{1}$ i $V_{4}$ mogu se izračunati na sljedeći način, ukoliko su poznati otpori $R_{1}, R_{2}, R_{3}, R_{4}$ i $V_{s}$ :

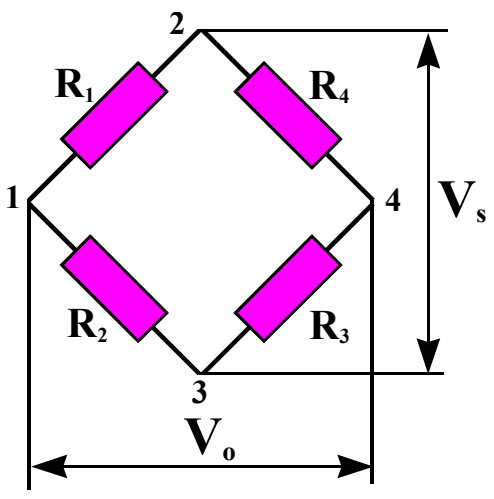

Sl. 4 - Vitstonov most

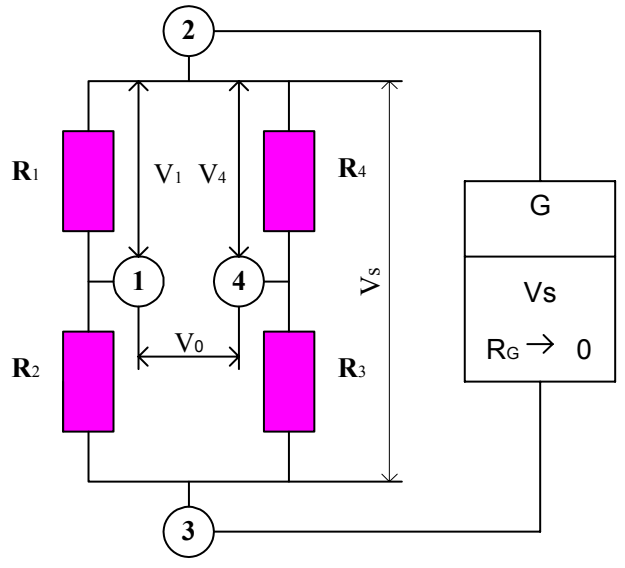

Sl. 5 - Princip rada Vitstonovog mosta

$V_{1}=\frac{R_{1}}{R_{1}+R_{2}} \cdot V_{s}$

$V_{4}=\frac{R_{4}}{R_{3}+R_{4}} \cdot V_{s}$

Razlika napona $V_{1}$ i $V_{4}$ predstavlja izlazni napon $V_{0}$.

$V_{0}=V_{s} \cdot\left(\frac{R_{1}}{R_{1}+R_{2}}-\frac{R_{4}}{R_{3}+R_{4}}\right)=V_{s} \cdot\left(V_{1}-V_{4}\right)$

Neizbalansiranost mosta definisana je kao relativni izlazni napon:

$\frac{V_{0}}{V_{s}}=\frac{R_{1}}{R_{1}+R_{2}}-\frac{R_{4}}{R_{3}+R_{4}}$

Postoje dva slučaja kada je most izbalansiran:

- otpori otpornika u mostu su jednaki $\left(R_{1}=R_{2}=R_{3}=R_{4}\right)$,

- odnos otpora u obe polovine mosta je isti $\left(R_{1} / R_{2}=R_{3} / R_{4}\right)$. 
U oba slučaja $V_{0} / V_{S}=0$ most je izbalansiran. Ako otpori u mostu $R_{1} \ldots R_{4}$ mijenjaju svoje vrijednosti za odgovarajuću razliku $\Delta R$, most nije izbalansiran i javlja se odgovarajući izlazni napon $V_{0}$. U ovom slučaju relativni izlazni napon je:

$$
\begin{aligned}
& \frac{V_{0}}{V_{S}}=\frac{1}{4} \\
& \left(\frac{R_{1}+\Delta R_{1}}{R_{1}+\Delta R_{1}+R_{2}+\Delta R_{2}}-\frac{R_{4}+\Delta R_{4}}{R_{3}+\Delta R_{3}+R_{4}+\Delta R_{4}}\right)
\end{aligned}
$$

Zbog činjenice da je $\Delta R_{i} \ll R_{i}$, relativni izlazni napon se može predstaviti na sljedeći način:

$$
\frac{V_{0}}{V_{S}}=\frac{1}{4}\left(\frac{\Delta R_{1}}{R_{1}}-\frac{\Delta R_{2}}{R_{2}}+\frac{\Delta R_{3}}{R_{3}}-\frac{\Delta R_{4}}{R_{4}}\right)
$$

Kako je $\Delta R_{i} / R_{i}=k \varepsilon_{i}$, relativni izlazni napon je:

$$
\frac{V_{0}}{V_{S}}=\frac{k}{4}\left(\varepsilon_{1}-\varepsilon_{2}+\varepsilon_{3}-\varepsilon_{4}\right)
$$

Prema tome, izlazni napon sa mosta $V_{0}$ je funkcija:

- napona napajanja mosta $V_{s}$,

- $k$-faktora mjerne trake,

- deformacija ili promjene napona u granama mosta $\varepsilon_{1} \ldots \varepsilon_{4}$.

\section{Prikaz metode istraživanja}

Eksperimentalno određivanje propelerske karakteristike dvotaktnog brodskog dizel motora, pomoću mjernih traka i personalnih računara beskontaktnom metodom, izvršeno je na brodu Mornari- ce Srbije i Crne Gore, čija je dužina 96,5 $\mathrm{m}$, širina $12,5 \mathrm{~m}$, a standardni deplasman 1470 t. Gaz broda na pramcu iznosi 2790 $\mathrm{mm}$, a gaz na krmi je $3240 \mathrm{~mm}$.

Brod pogone dva glavna dizel motora $\mathrm{i}$ jedna gasna turbina preko zasebnih vratilnih vodova. Na svakom vratilnom vodu nalazi se trokrilni propeler sa fiksnim krilima. Dizel motori prema konstrukcionom obliku su linijski, u dva reda po devet cilindara u vertikalnom bloku. Tip motora je 68B, dvotaktni, nominalne snage jednog motora $5880 \mathrm{~kW}$. Gorivo koje motori koriste je dizel DS, a ulje SAE-50. Pri izvođenju eksperimenta brod je pogonjen sa dva dizel motora, a gasna turbina nije radila. Pri tome se turbinski vratilni vod slobodno obrtao.

Pozicija broda sa koje je započeto snimanje propelerske karakteristike je azimut pravi $\omega_{\mathrm{p}}=047$ a daljina $\mathrm{d}=0,3$ $\mathrm{M}$ od ostrva Mamula. Kurs broda tokom snimanja karakteristika bio je $\mathrm{k}_{\mathrm{p}}=136$, a stanje mora 1 do 2 . Temperatura vazduha bila je $12^{\circ} \mathrm{C}$, barometarski pritisak 1005 mbar, vjetar jugoistočni 11 čv, a relativna vlažnost $68 \%$. Temperatura mora iznosila je $14^{\circ} \mathrm{C}$.

Mjerenje je izvršeno postavljanjem mjernih traka i mjerne opreme na vratilni vod lijevog glavnog motora. Mjerne trake se postavljaju na vratilnom vodu između spojnice motora i potisnog (odrivnog) ležaja. Lijevi glavni motor od ugradnje imao je 2912,30 časova pogona. Do sada na motoru nije izvršen ni jedan generalni remont. Dio vratilnog voda na kojem su postavljene mjerne trake je prstenastog poprečnog presjeka dimenzija 260/80 mm. Vratila su izrađena od kovanog čelika, čiji je modul elastičnosti $\mathrm{E}=215 \mathrm{kN} / \mathrm{mm}^{2}$. Shematski prikaz po- 


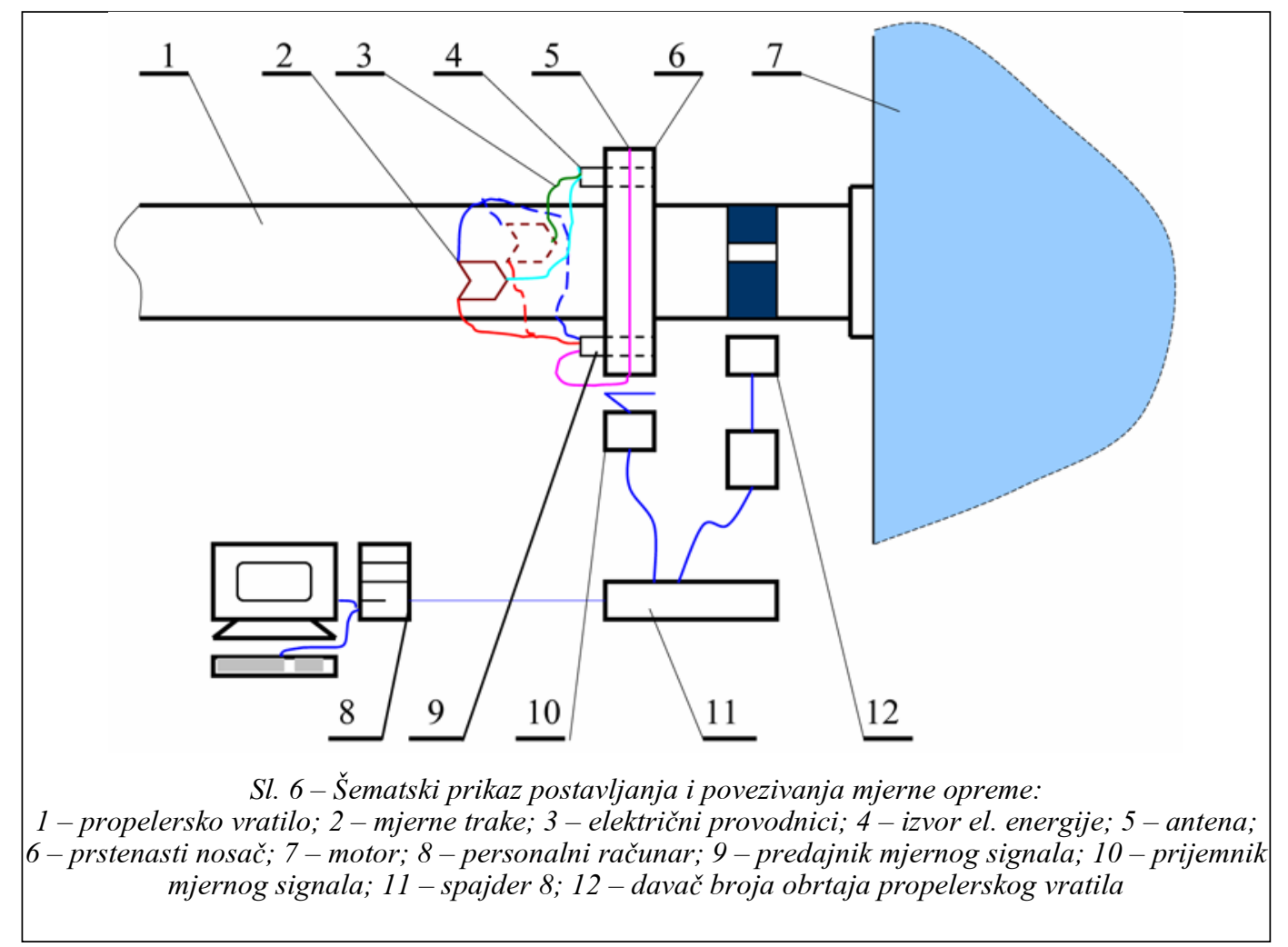

stavljanja i povezivanja mjerne opreme prikazan je na slici 6 . Na vratilo su postavljena dva para mjernih traka tip XY21$6 / 350$ koje su povezane u Vitstonov most. Trake su međusobno postavljene pod uglom od $180^{\circ}$, a njihovo napajanje izvršeno je izvorom jednosmjernog napona od $9 \mathrm{~V}$. Mjerni signal sa Vitstonovog mosta odvodi se do predajnika i preko antene predaje prijemniku mjernog signala. Izvor električne energije, predajnik i antena postavljeni su na prstenasti disk koji mora biti od plastične mase radi eliminacije smetnji, a postavlja se na vratilo. Na vratilo se po cijelom obimu postavlja još i tamna traka sa svijetlom trakom preko nje, koja omogućava da se registruje broj obrtaja vratilnog voda. Pored vratilnog voda, na odgovarajućem razmaku, postavljaju se prijemnik mjernog signala i davač broja obrtaja vratilnog voda. Prijemnik mjernog signala $i$ davač broja obrtaja povezani su sa elektronskim mjernim uređajem Spider 8.

Spider 8 povezuje se sa personalnim računarom, a program koji omogućava mjerenje i obradu izmjerenih podataka je catman 3.0. Navedena oprema, odnosno hardver i softver proizvedeni su u njemačkoj firmi HOTTINGER BALDWIN MESSTEHNIK (HBM).

Spider 8 je elektronski mjerni uređaj za mjerenje promjenljivih fizičkih veličina, kao što su naprezanje, sila, pritisak, ubrzanje i temperatura. Spaja se na personalni računar preko veze za štampač. Sva podešavanja uređaja vrše se softverski, odnosno putem komandi na perso- 
nalnom računaru. Ima četiri digitalna pojačivača koji rade na frekvenciji $4,8 \mathrm{kHz}$ i osam kanala numerisanih brojevima od 0 do 3 i od 4 do 7 . Svaki kanal radi sa odvojenim A/D konvertorom koji dopušta mjerne odnose od $1 / \mathrm{s}$ do $9600 / \mathrm{s}$, što znači da u potpunosti pokriva opseg mehaničkih mjernih zadataka.

A/D konvertori su sinhronizovani kako bi se osiguralo istovremeno mjerenje na svim kanalima. Moguće je spojiti osam uređaja u kaskadu, što daje ukupno 64 kanala. U tom slučaju nisu potrebna nikakva dodatna podešavanja, a računar će prepoznati ovakav sistem međusobno povezanih uređaja kao jednu cjelinu sa
64 kanala koji su međusobno sinhronizovani [4].

Catman 3.0 je program predviđen za $\mathrm{rad} \mathrm{u}$ operativnom sistemu MS Windows, i dozvoljava korisniku da se koncentriše na stvarne zadatke mjerenja. Program Catman predviđen je za korišćenje interaktivnog ili automatskog mjernog softvera, ali je moguća i njegova upotreba kao razvojnog okruženja za posebne aplikacije [3].

Ovaj softver može da obavlja različite zadatke, kao što su: konfiguracija mjerne opreme, definisanje i automatizacija mjernih koraka, vizuelno prikazivanje rezultata, arhiviranje rezultata, anali-

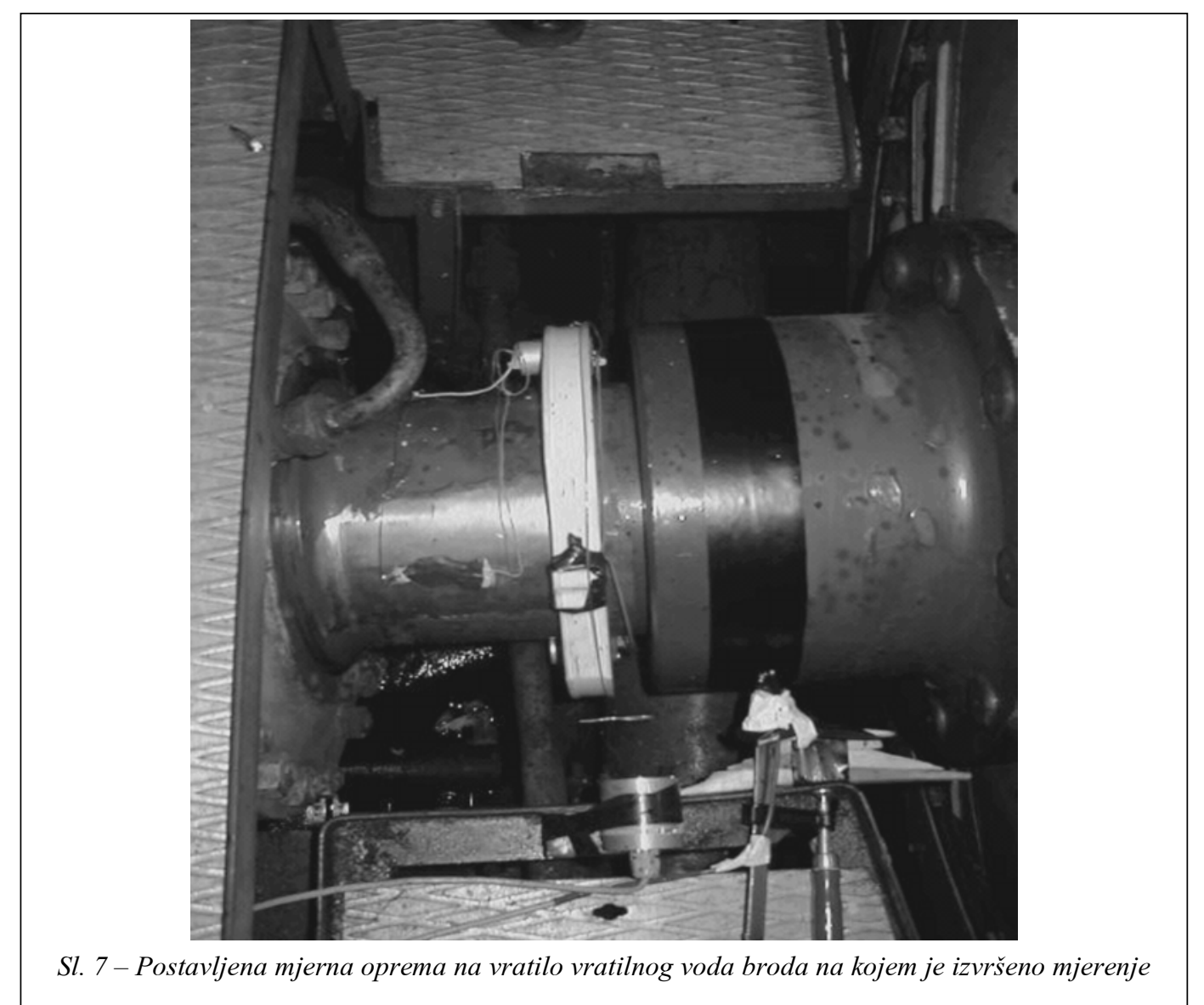


za rezultata, razvoj okruženja za specijalne potrebe korisnika.

Rezultati mjerenja pomoću ovog programa dobijaju se u četiri koraka.

U prvom koraku prepoznaju se priključeni uređaji i dodjeljuju im se imena preko korisničkog interfejsa, a u drugom koraku vrši se konfiguracija pojačivačkog sistema. Program sadrži drajvere i virtuelne kontrolne panele za sve HBM pojačivačke sisteme.

U trećem koraku određuju se ulazno-izlazni kanali kojima se dodjeljuju odgovarajući brojevi, kao i opcije automatskog čuvanja podataka u pojedinim datotekama ili bazi podataka i u četvrtom koraku se obavlja mjerenje i prikazivanje izmjerenih rezultata.

Mjerne trake koje su korištene pri mjerenju deformacija vratila specijalnog su oblika serije Y, tip XY21-6/350, izradene od dvije trake, tako da je formiran par mjernih traka (slika 8). Unutrašnji otpor para mjernih traka je $350 \Omega$, a osjetljivost mjerne trake je $k=2,07$. Tempe-

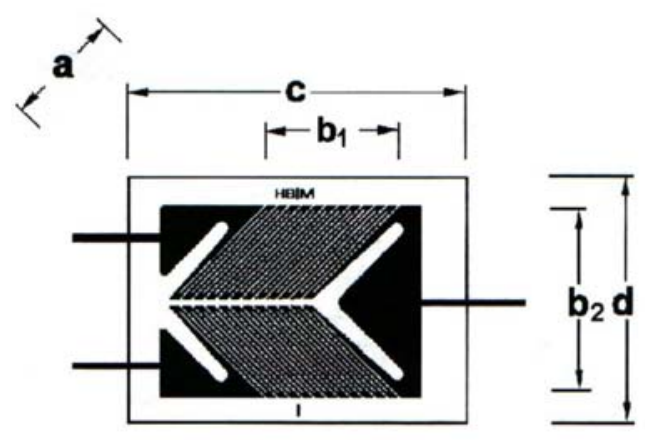

Sl. 8 - Izgled mjerne trake XY21-6/350 raturno područje u kom se mjerne trake mogu primjenjivati iznosi od -10 do $45^{\circ} \mathrm{C}$. Maksimalni napon napajanja mjernih traka je $19 \mathrm{~V}$.

Dimenzije mjernih traka su sljedeće: $a=6 \mathrm{~mm}, b_{1}=7,8 \mathrm{~mm}, b_{2}=10 \mathrm{~mm}$, $\mathrm{c}=17,5 \mathrm{~mm} \mathrm{i} \mathrm{d}=12,7 \mathrm{~mm}$.

Da bi se započelo sa procesom mjerenja potrebno je u program Catman unijeti vrijednosti polaznih podataka koji karakterišu vratilo, a to su:

- modul elastičnosti $E$,

- modul smicanja $G$,

- Poasonov koeficijent $v$,

- polarni moment otpora poprečnog presjeka vratila $W_{p}$,

- moment torzije $M_{d}$.

Pored navedenih podataka potrebno je unijeti i podatke o kalibraciji mjerne opreme.

Polarni moment otpora, za prstenasti poprečni presjek, određuje se prema obrascu iz otpornosti materijala:

$W_{p}=\frac{D^{4}-d^{4}}{16 \cdot D} \cdot \pi$

$W_{p}=\frac{26^{4}-8^{4}}{16 \cdot 26} \cdot \pi=3418\left[\mathrm{~cm}^{3}\right]$

Modul smicanja određuje se izrazom:

$G=\frac{E}{2 \cdot(1+v)}$

Za čelik $v=0,3$.

$$
G=\frac{215}{2 \cdot(1+0,3)}=8269,23\left[\frac{\mathrm{kN}}{\mathrm{cm}^{2}}\right]
$$

Moment torzije određuje se [2]: 


$$
\begin{aligned}
& M_{d}=\frac{1}{2} \cdot W_{p} \cdot G \cdot \varepsilon_{i} \\
& M_{d}=\frac{1}{2} \cdot 3418 \cdot 8269,23 \cdot \varepsilon_{i}= \\
& =141321,1407 \cdot \varepsilon_{i}[\mathrm{kNm}]
\end{aligned}
$$

$\varepsilon_{i}$ predstavlja izmjerenu vrijednost deformacije vratila koja uzima u obzir izvršenu kalibraciju.

Da bi se u postupku mjerenja izbjegle sistemske greške, izvršen je postupak kalibracije mjerne opreme. U ovom slučaju primjenjena je metoda Shunt kalibracije, pomoću jednog otpornika vezanog paralelno u Vitstonovom mostu. Kod ove metode kalibracije, a uzimajući u obzir i vrstu primjenjene mjerne trake, izlaznom naponu mosta od $2 \mathrm{mV} / \mathrm{V}$ odgovara deformacija mjerne trake od 1000 $\mu \mathrm{m} / \mathrm{m}$, što se mora uzeti u obzir pri odredivanju momenta torzije.
Na taj način snimljena je propelerska karakteristika navedenog motora $\mathrm{i}$ to od minimalnog broja obrtaja koljenastog vratila motora $273 \mathrm{~min}^{-1}$ do broja obrtaja koji je postignut $\mathrm{u}$ datim uslovima $602 \mathrm{~min}^{-1}$. Snaga je snimana u devet radnih tačaka i to za svaku tačku u intervalu od 10 sekundi. U svakom intervalu mjerenja od 10 sekundi izmjereno je po 250 vrijednosti snage, gdje su registrovane minimalne vrijednosti, maksimalne vrijednosti, srednja vrijednost snage i standardna devijacija izmjerenih vrijednosti. Izmjereni rezultati prikazani su u tabeli. Na slici 9 grafički je prikazana promjena snage za svaki broj obrtaja koljenastog vratila na osnovu izmjerenih vrijednosti deformacija vratila vratilnog voda $\mathrm{u}$ mjerenom intervalu od 10 sekundi. Za dobijanje propelerske karakteristike korištene su izmjerene srednje vrijednosti snage na svakom intervalu. Propelerska karakteristika dizel motora grafički je prikazana (kriva 3) na slici 10 .

\begin{tabular}{|c|c|c|c|c|c|c|c|c|c|}
\hline $\mathbf{n}$ min $^{-1}$ & 273 & 316 & 355 & 397 & 447 & 553 & 566 & 586 & 602 \\
\hline $\mathbf{P}_{\text {sr }} \mathrm{kW}$ & 241,27 & 414,28 & 612,22 & 870,33 & 1283,98 & 2432,64 & 2587,33 & 2902,47 & 3088,79 \\
\hline $\mathbf{P}_{\min } \mathrm{kW}$ & 62,43 & 226,69 & 463,44 & 622,73 & 962,15 & 2278,44 & 2488,52 & 2778,07 & 2936,86 \\
\hline $\mathbf{P}_{\max } \mathrm{kW}$ & 453,84 & 559,71 & 765,04 & 1145,26 & 1597,44 & 2566,82 & 2704,51 & 3039,06 & 3303,16 \\
\hline $\boldsymbol{\sigma}$ & 80,57 & 71,49 & 66,68 & 157,81 & 197,28 & 51,34 & 42,58 & 52,01 & 60,00 \\
\hline
\end{tabular}

Snaga koju motor preko vratilnog voda predaje propeleru iznosi:

$$
\begin{aligned}
& P=M_{d} \cdot \omega=\frac{2 \cdot \pi \cdot n}{60} \cdot 141321,1407 \cdot \varepsilon_{i}[\mathrm{~kW}] \\
& =14791,6123 \cdot n \cdot \varepsilon_{i}[\mathrm{~kW}]
\end{aligned}
$$

$n$ je broj obrtaja osovinskog voda.

Izraz za snagu unosi se kao polazni podatak u program catman, koji omogućava određivanje snage predate od motora preko vratilnog voda propeleru u svakom trenutku. Promjena snage može se kontinuirano pratiti u dužem intervalu ili u intervalu od nekoliko sekundi, zavisno od potrebe.
Na slici 10 prikazane su gornja granična karakteristika motora (kriva 1) i propelerska karakteristika vožnje ,naprijed“ (kriva 2), koje je dao proizvođač u uputstvu za eksploataciju motora $68 \mathrm{~B}$, a

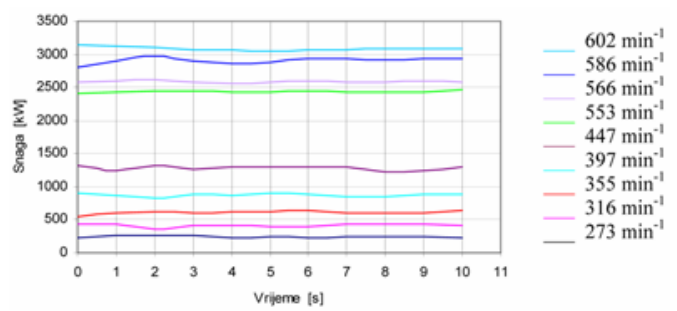

Sl. 9 - Promjena snage dizel motora $u$ intervalu od 10 sekundi za brojeve obrtaja od 273 do 602 $\left[\mathrm{min}^{-1}\right]$ 


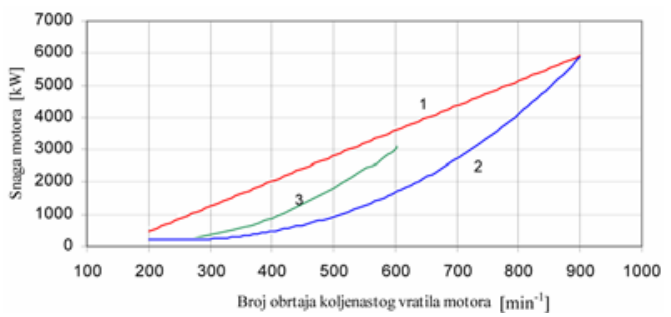

Sl. 10 - Snimljena propelerska karakteristika (kriva 3)

izrađene su na osnovu dobijenih rezultata pri ispitivanju dizel motora na brodu nakon novoizgradnje broda [6]. Pri izvođenju protokola ispitivanja brod je pogonjen sa dva dizel motora, a gasna turbina nije radila, pri čemu se turbinski vratilni vod slobodno obrtao. Motori su radili u uslovima ustaljenog režima, na osnovu čega se može konstatovati da su približno isti uslovima u kojima je izveden eksperiment.

Sa slike 10 se vidi da se snimljena propelerska karakteristika pomoću mjernih traka znatno razlikuje od propelerske karakteristike koju je dao proizvođač u uputstvu, i predstavlja rad motora na režimu ,teškog propelera“. Riječ je, naime, o tome da brod nije bio na doku četiri godine, zbog čega nije očišćen njegov podvodni dio (oplata podvodnog dijela broda i propeleri su „obrasli“"), što predstavlja veliki otpor kretanju.

\section{Zaključak}

Eksperimentalni podaci dobijeni metodom koja je korištena pri snimanju propelerske karakteristike na konkretnom brodu pokazali su da motor radi po krivoj „teškog propelera“, što govori o tome da brod ne može postići potrebnu brzinu kao kada su podvodni dio broda i propeleri čisti. Da bi se postigla potrebna brzina broda potrebno je povećati broj obrtaja motora, što bi dovelo do njegovog preopterećenja. Iz snimljene propelerske karakteristike uočljivo je da se već pri $600 \mathrm{~min}^{-1}$ kriva bliži spoljnjoj graničnoj karakteristici motora, odnosno svi parametri radnog procesa su blizu gornjih granica. Maksimalni projektovani broj obrtaja motora iznosi $900 \mathrm{~min}^{-1}$, što govori o tome da se motor ne smije opteretiti više od polovine nominalne snage. Takođe, kada je motor preopterećen povećava se potrošnja goriva, a smanjuje resurs motora.

Kao i druge poznate metode, i ova ima svoje prednosti i nedostatke. Prednosti su:

- mjerne trake i davači na principu mjernih traka veoma su malih masa, što znači da ne postoje inercijalne sile;

- mjerne trake ne utiču na objekat ispitivanja,

- mjerne trake su se pokazale kao veoma pogodne za dugotrajna dinamička ispitivanja kod velikog broja ciklusa (rad motora SUS),

- davači na principu mjernih traka mogu izdržati kako niske tako i veoma visoke pritiske (od 10-7 mbar do 10000 bar),

- u pogledu gornje granične frekvencije ne postoje ograničenja, što znači da mjerne trake, kada su ispravno postavljene, prate sve dinamičke promjene na objektu ispitivanja,

- kada se mjerne trake postave na objekat ispitivanja, mogu se zaštititi specijalnom gumom, tako da se ponovna mjerenja mogu vršiti po potrebi i posle dužeg perioda.

Nedostaci metode su:

- maksimalne temperature na kojima se mogu primjeniti mjerne trake su do 
$350^{\circ} \mathrm{C}$, izuzev specijalnih davača koji imaju primjenu i na većim temperaturama;

- mjerne trake su osjetljive na tako-

zvana parazitska opterećenja;

- osjetljive su na vlagu, tako da je potrebno izvršiti zaštitu sa specijalnim gumama.

Može se konstatovati da se ova metoda može uspješno primjeniti za kontrolu stanja trupa i propelera, kao i provjere da li propeleri odgovaraju brodskom trupu i glavnim motorima.
Literatura:

[1] Gitis, V. J.; Bondarenko, V. L.; Jefimov, T. P., Poljakov, J. G.; Črbanov, B. M.: Teorijske osnove eksploatacije brodskih dizel motora (prevod s ruskog), SSNO, Beograd, 1973.

[2] Hoffmann, K.: An Introduction to Measurements using Starin Gages, Hottinger Baldwin Messtechnik GmbH, Darmstadt, 1989.

[3] CATMAN 3.0 32-bit measurement technique softvare for MS-Windows 95/98 NT, HBM Darmstadt, 1999.

[4] Spider8-the friendly alternative for PC-based measurements, HBM Darmstadt, 1997.

[5] Jeremić, M. B.: TEROTEHNOLOGIJA-Tehnologija održavanja tehničkih sistema, Eskod Kragujevac, 1992.

[6] Dizel motor 68B, Uputstvo za eksploataciju (prevod), SSNO, Beograd, 1985 


\begin{tabular}{|c|c|c|c|c|c|c|c|c|c|}
\hline $\mathbf{n}$ min $^{-1}$ & 273 & 316 & 355 & 397 & 447 & 553 & 566 & 586 & 602 \\
\hline $\mathbf{P}_{\text {sr }} \mathrm{kW}$ & 241,27 & 414,28 & 612,22 & 870,33 & 1283,98 & 2432,64 & 2587,33 & 2902,47 & 3088,79 \\
\hline $\mathbf{P}_{\min } \mathrm{kW}$ & 62,43 & 226,69 & 463,44 & 622,73 & 962,15 & 2278,44 & 2488,52 & 2778,07 & 2936,86 \\
\hline $\mathbf{P}_{\max } \mathrm{kW}$ & 453,84 & 559,71 & 765,04 & 1145,26 & 1597,44 & 2566,82 & 2704,51 & 3039,06 & 3303,16 \\
\hline $\boldsymbol{\sigma}$ & 80,57 & 71,49 & 66,68 & 157,81 & 197,28 & 51,34 & 42,58 & 52,01 & 60,00 \\
\hline
\end{tabular}

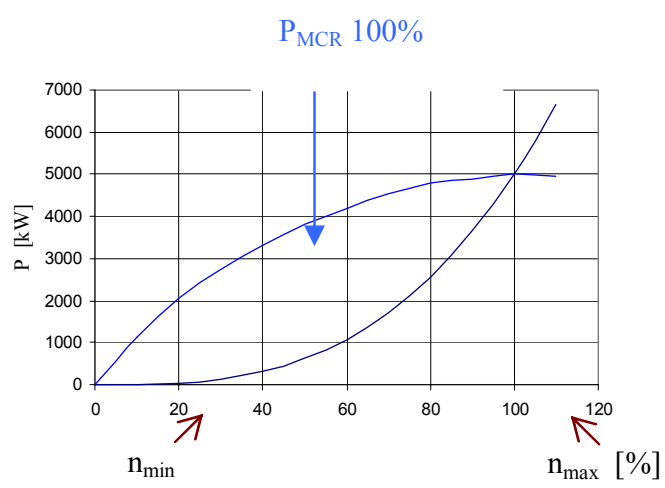

$\mathrm{P}_{\mathrm{e}}=\mathrm{k}_{1} \mathrm{n}^{3}$

Sl. 1 - Propelerska i spoljna karakteristika motora

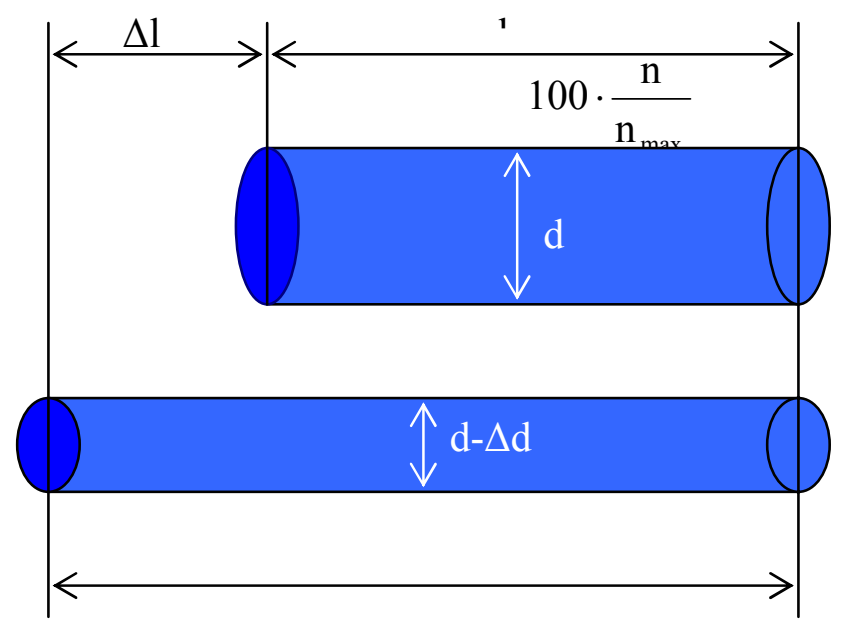

$$
l+\Delta l
$$

Sl. 2 - Deformacija objekta usled opterećenja 


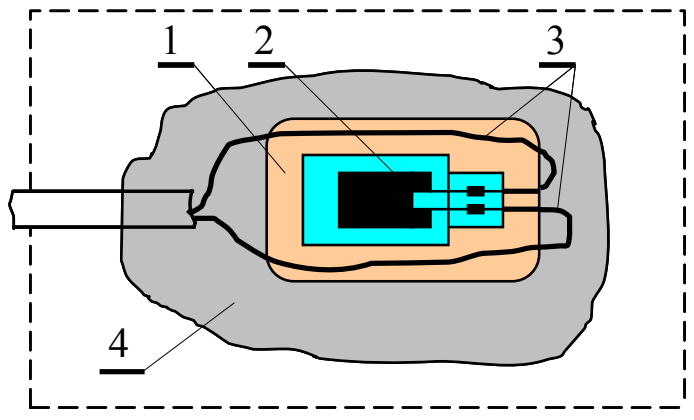

Sl. 3 - Postavljena mjerna traka na objekat ispitivanja:

1 - pripremljena površina na objektu za mjerenje;

2 - postavljena mjerna traka na objekat za mjerenje;

3 - električni provodnici za napajanje mjerne trake $i$ 4 - specijalna guma za zaštitu mjerne trake

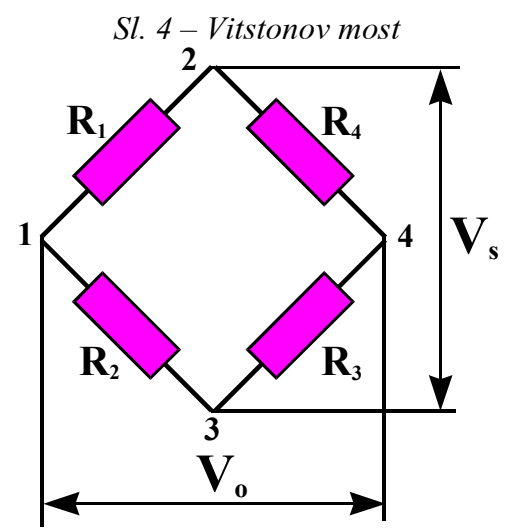




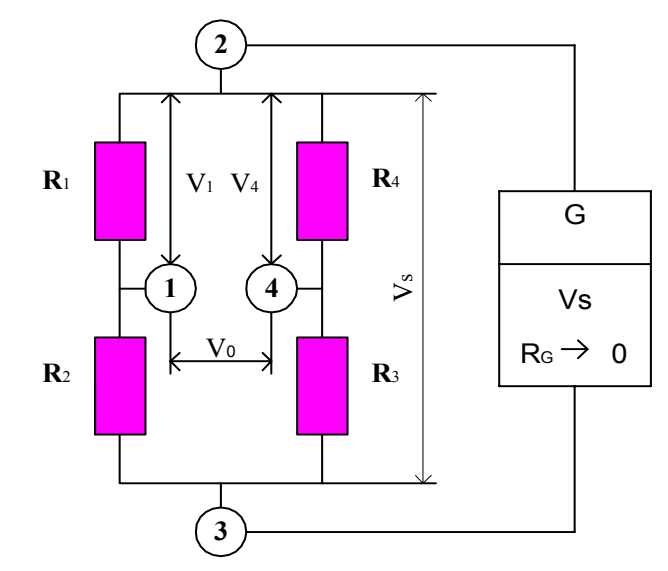

Sl. 5 - Princip rada Vitstonovog mosta

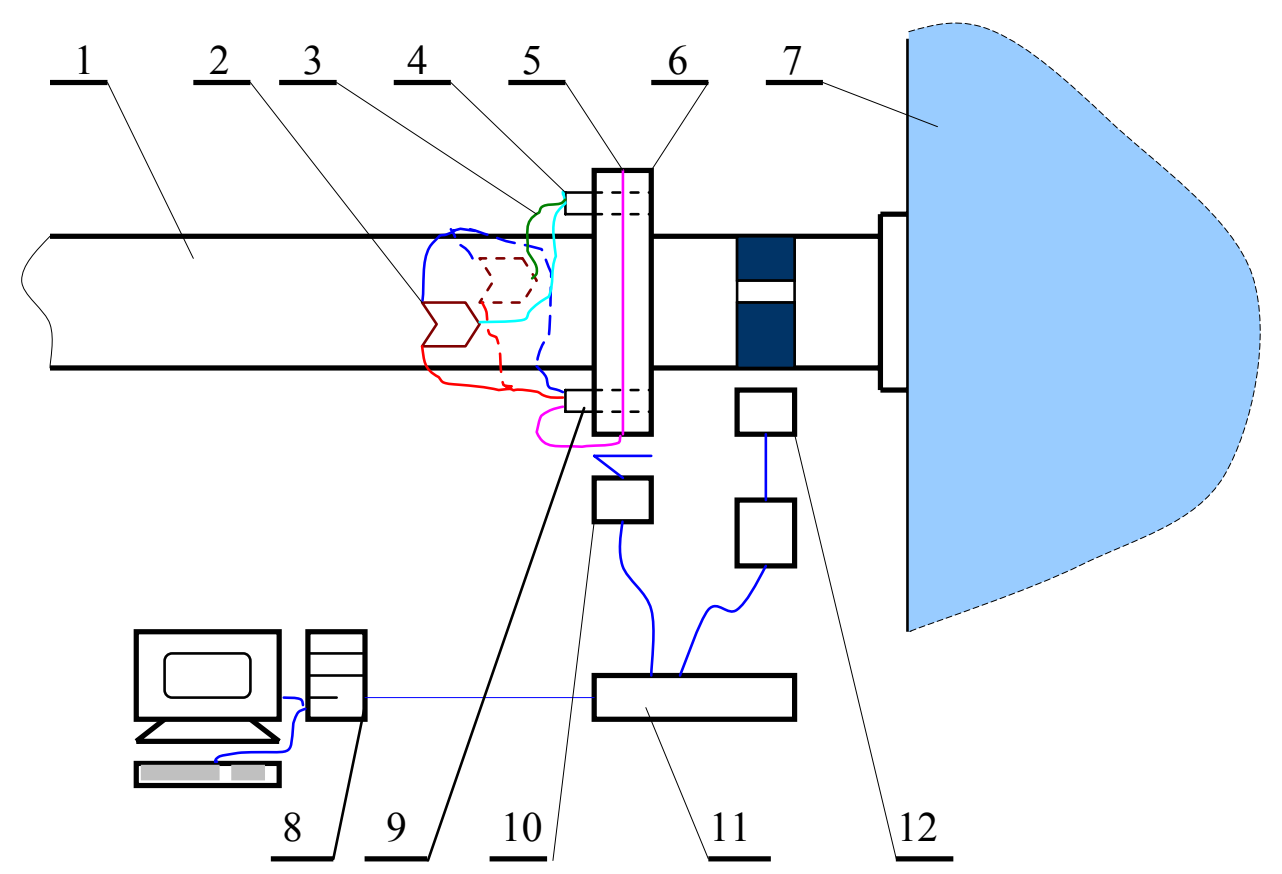

Sl. 6 - Šematski prikaz postavljanja i povezivanja mjerne opreme:

1 -propelersko vratilo; 2 -mjerne trake; 3 - električni provodnici; 4 -izvor el. energije; 5 - antena; 6 - prstenasti nosač; 7 - motor; 8 - personalni računar; 9 - predajnik mjernog signala; 10 - prijemnik mjernog signala; 11 - spajder 8; 12 -davač broja obrtaja propelerskog vratila 


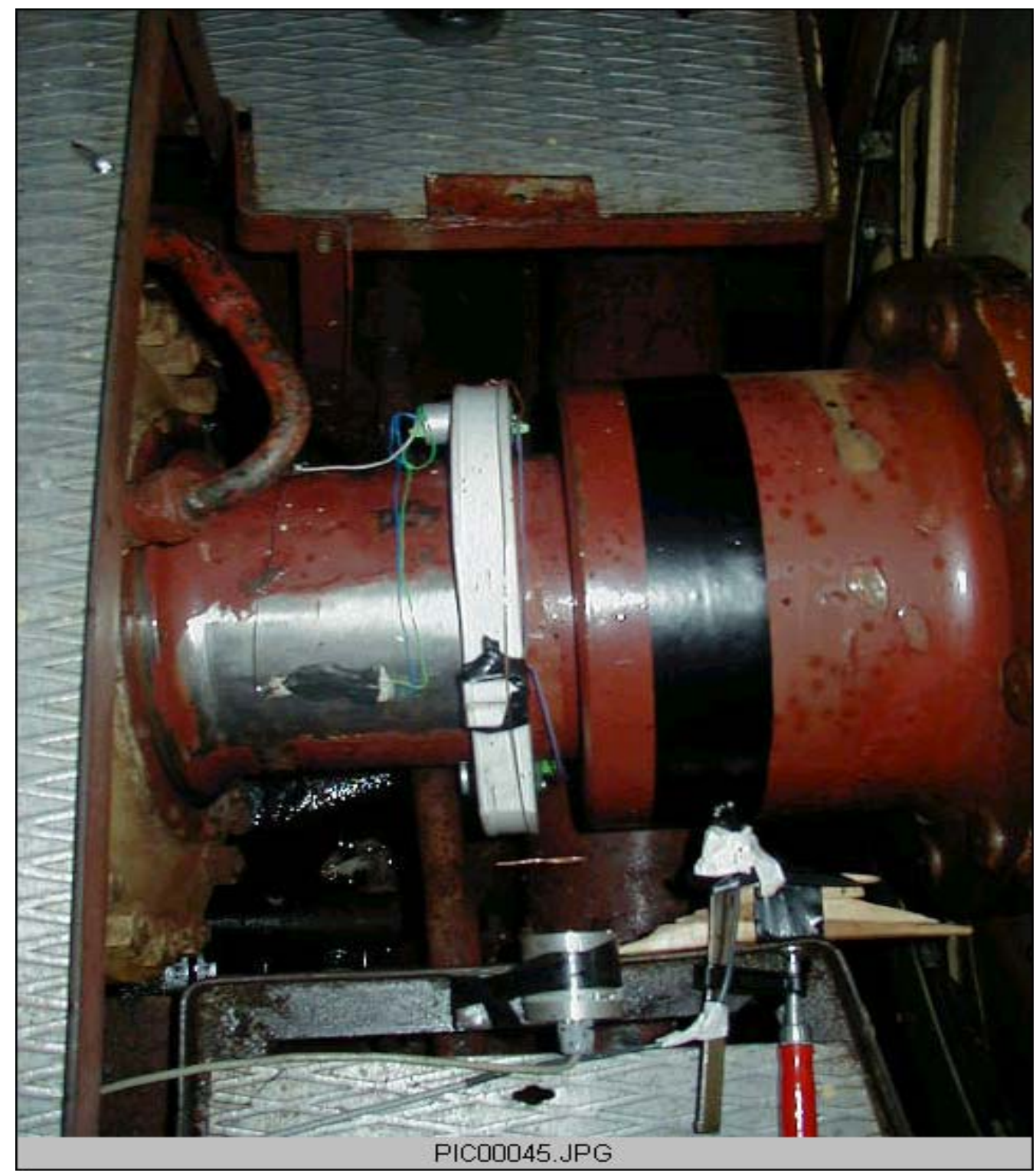

Sl. 7 - Postavljena mjerna oprema na vratilo vratilnog voda broda na kojem je izvršseno mjerenje 


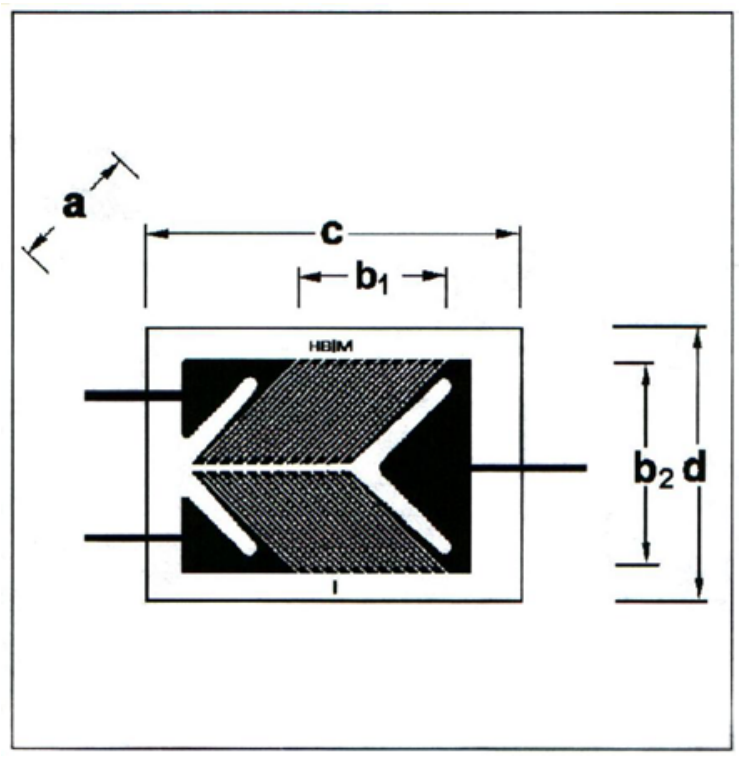

Sl. 8 - Izgled mjerne trake XY21-6/350

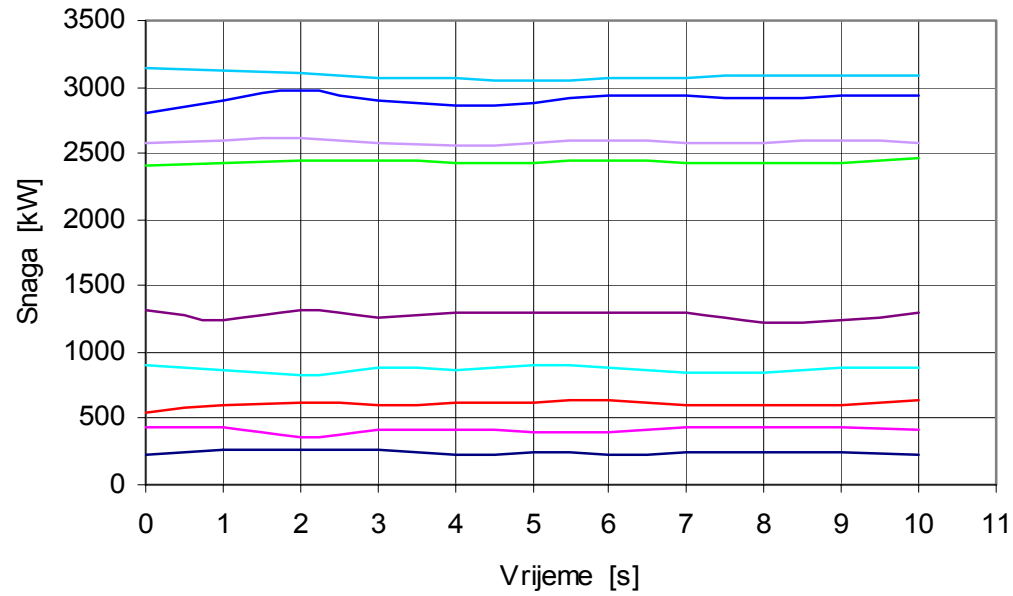

$602 \mathrm{~min}^{-1}$

$586 \mathrm{~min}^{-1}$

$566 \mathrm{~min}^{-1}$

$553 \mathrm{~min}^{-1}$

$447 \mathrm{~min}^{-1}$

$397 \mathrm{~min}^{-1}$

$355 \mathrm{~min}^{-1}$

$316 \mathrm{~min}^{-1}$

$273 \mathrm{~min}^{-1}$

Sl. 9 - Promjena snage dizel motora u intervalu od 10 sekundi za brojeve obrtaja od 273 do 602 [ $\mathrm{min}^{-1}$ ] 


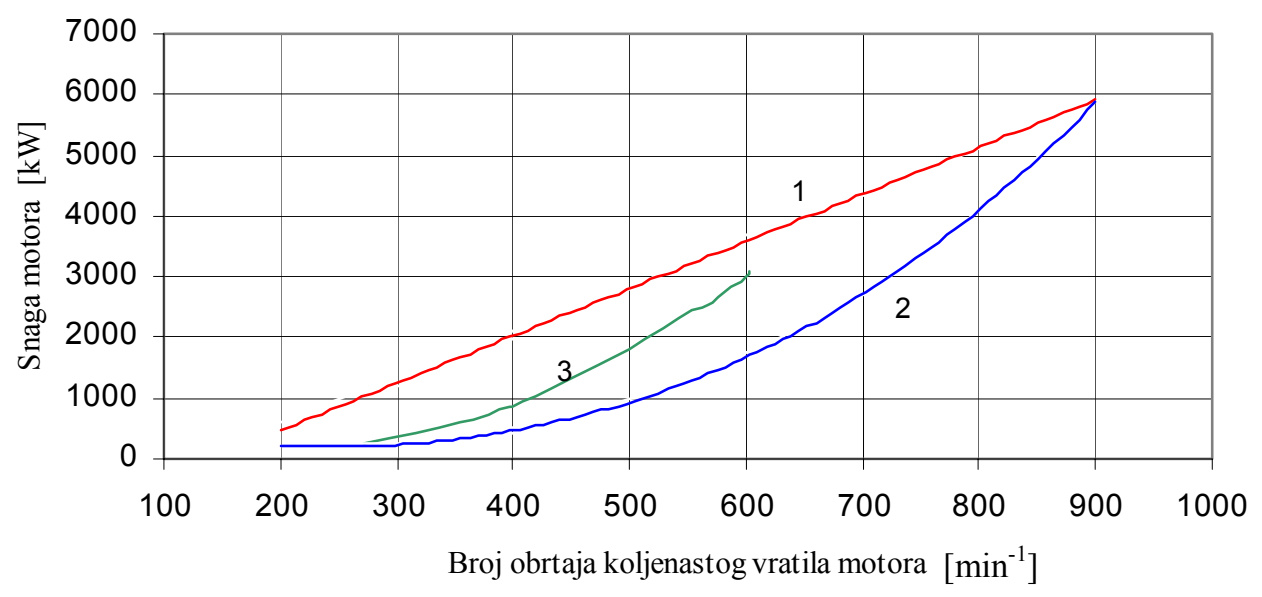

Sl. 10 - Snimljena propelerska karakteristika (kriva 3) 